\title{
Investigation and Analysis of Agricultural Information Construction in the Economically Weak Rural Areas of Beijing
}

\author{
Wei-Wei ZHANG ${ }^{1}$, Hong LI', a \\ ${ }^{1}$ Beijing Academy of Agriculture and Forestry Sciences, No.9 Shu Gang Hua Yuan Middle Road, Beijing 100097, China \\ a Corresponding author:lihsdf@sina.com
}

\begin{abstract}
The agricultural information construction in the economically weak rural areas of Beijing may promote mutual conversion between the informatization of traditional agricultural production elements and the factored information production, which provides the new opportunities and conditions for agricultural development. In the present study, the current status of the information construction, information personnel, the information operational capability of villagers and the reasons affecting their information utilization in the village was investigated and analyzed by questionnaire survey, which offers the targeted suggestions for advancing the agricultural information level in the economically weak rural areas of Beijing, including 1) establish effective internet environment within the village to supply effective access to the Internet for poor villagers; 2)emphasize the internet operational training for the villagers; 3 ) construct the internet platform to provide the communication platform and 4) reinforce the training of village level scientific and technical information personnel.
\end{abstract}

\section{Introduction}

Rural informatization is an important part of the national information construction, and it is also the essence of the construction of the new socialist countryside.

As the capital city of our country, Beijing has always attached great importance to the economic and social development of the economically weak area. The rural economy weak region in Beijing is relatively wide, the living area is relatively scattered, and the spendable income of the farmers is limited. The "Last kilometre" issue, as the biggest barrier of the rural informatization, is related to whether the achievement of information technology can really benefit ordinary people, as well as the process of constructing a new socialist countryside. In the present study, we explored the agricultural information construction and its popularizing status in Beijing rural region with weak economic development by questionnaire survey, which offers the targeted suggestions for improving the agricultural information level in the economically weak rural area of Beijing.

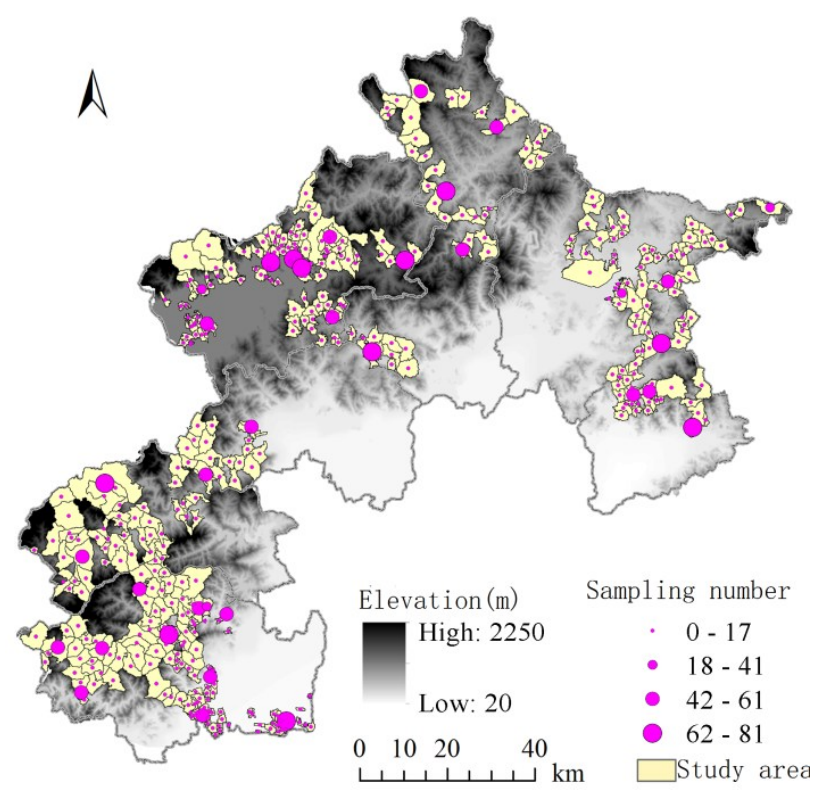

Figure 1. The Location of Study Area and The Questionnaire Sample Distribution

\section{Research Methods}

In the present study, questionnaire survey and interview were utilized to thoroughly mine the construction and popularization of agricultural information in the economically weak rural areas of Beijing. The current 
status of the information construction, information personnel, the information operational capability of villagers and the reasons affecting their information utilization in the village were investigated. The statistical analysis method was used to process data, and the Microsoft Excel software was used.

The research objects were divided into two levels, the village level and the peasant household. The village level objects was comprised of 393 villages in 32 townships, and the farmer level included 2210 rural household in 35 administrative villages in the economically weak rural areas of Beijing. Of these, 391 valid questionnaires were retrieved out of the 393 village level questionnaires, and 1851 out of 2210 were valid for the peasant household level. The general situation of the survey object is geographically isolated, small population size, old in age, low cultural level, single industrial structure with poor overall strength, and big proportion of young migrant workers.

\section{The Current Developmental Status of Agricultural Informatization in The Economically Weak Rural Areas of Beijing}

The statistical analysis was performed infrastructure construction of information in gully region, agricultural information system construction and personal information qualities of villagers.

\subsection{The Status of the Information Infrastructure Construction}

The information network infrastructure exhibited low level in the economically weak rural areas of Beijing with no optical fiber in any of the investigated village. However, telephone was available in every village, and it was convenient for villagers to install the telephone. In addition, cell phone was popularized with the rate over $95 \%$, and even the poorest household possessed a cell phone. Convenient and fast was the main reason for the high rate of mobile phone, but the high cost inhibited the use rate of cell phones, which was about $45.4 \%$. The penetration rate of TV was as high as $98 \%$ in the mountain region, but the rate was low for the cable. The broadcast and cable broadcast were available in all investigated villages. Moreover, the rural information stations were established in the townships, and the survey revealed that the ordinary operational effect, no effective service and never been to never heard of accounted for $49.4 \%, 15.2 \%$ and $25.2 \%$ respectively. Only $10.2 \%$ agreed on the desired effect of the station, which demonstrated that the insufficient self advertisement resulted in the lack of understanding and utilization of the station. Secondly, the service station did not play its due function because of the weak service ability.

\subsection{The Status of Agricultural Information System Construction in the Village}

By visiting the villages with the rural management system, the information management function of eight aspects was accomplished via the system, including rural population in the village, labor employment, the income of the farmers, rural finance, the party management, contract management, collective asset management and the publication of village affairs. The utilization of the system was under the superior guidance, but its main services in the government business needs cannot genuinely serve the villagers (Figure 2). On one hand, the government's initial investment is mainly to serve the level of government itself, but the lack of data foundation construction makes this service not exactly the best. On the other hand, the information service that cannot serve the rural areas certainly will not be valued in the village, so the data collection is not effectively guaranteed.

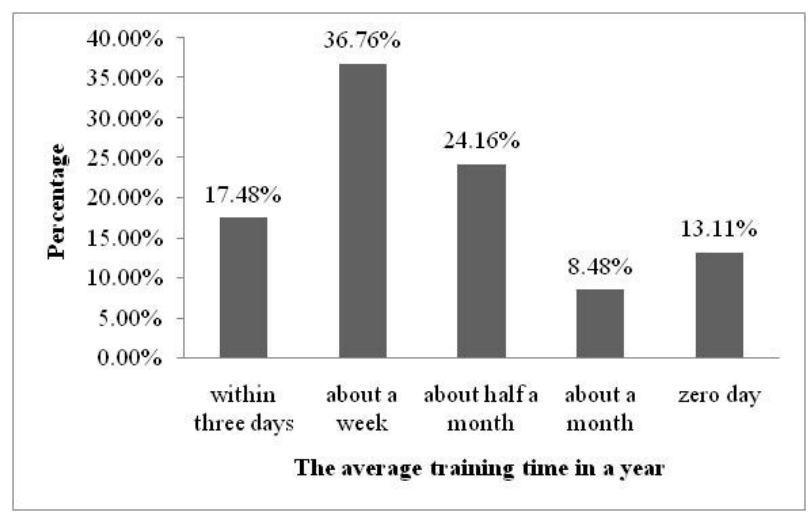

Figure 2. The Status of Village-Level Agricultural Information System Service

Currently, the survey on the service provided by agricultural information network indicated that redundant content with no novelty, weak pertinence, lack of interaction and poor design accounted for $26.4 \%, 28.4 \%$, $24.5 \%$ and $3.5 \%$, respectively. Therefore, as the social development and the improvement of farmer personal quality, the professional content of the website, the practicality of the content and the interaction of the website have been paid more attention.

As the most distal management organizations of administrative management, the village is the most effective sources of information entities. To break the "Last kilometre", government should adjust ideas to mine demand and strengthen the practicality and pertinence of information construction with village level as the construction unit.

\subsection{The Status of Information Service Ability in the Village}

The ability of village level information service depends on the level of village information officer. Overall, 391 villages of 32 townships and 391 information officers were involved in the investigation, one officers per village. From the perspective of age, officers born at $1960 \mathrm{~s}, 1970 \mathrm{~s}, 1980 \mathrm{~s}$ and $1990 \mathrm{~s}$ accounted for $23.14 \%$, 
$52.44 \%, 15.95 \%$ and $8.48 \%$, respectively. Officers born at 1970 s are the largest proportion in the survey.

Secondly, from the perspective of training length, few opportunities are available for the officers to attend a whole training program, although many information trainings are held in Beijing each year, or the position personnel of village information officers is not fixed with substantial mobility, so the proportion of officers who can accomplish the whole training process to all the training attendee is only $8.48 \%$ (Figure 3 ). Thirdly, from the perspective of degree, most officers hold a highschool degree, and the officers born in the $80 \mathrm{~s}$ and $90 \mathrm{~s}$ hold associate degree and above, but their computer professional level is relatively low, so their professional skills are mainly dependent on self learning and government training.

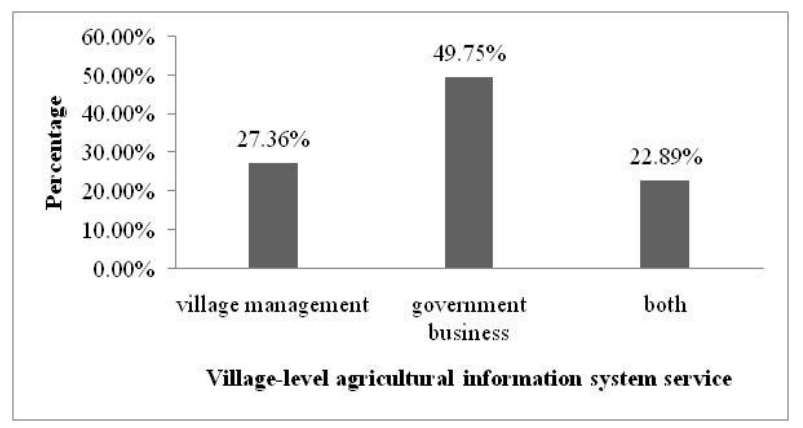

Figure 3. The Proportion of Officers Who Can Accomplish Training Process

Based on the age structure distribution and training time for the information officer, on one hand, the age structure is not reasonable, and their cultural level is low, suggesting the insufficient attention to rural information officers from the government. On the other hand, the information offers in the village is not properly organized, and their stipend is low (1000/year), therefore, the information staff is often temporarily part-timed by the relevant personnel with great mobility, leading to the cost increase of government training and unsatisfactory effect.

\subsection{The Status of Villagers' Information Quality}

For the 1851 investigated households, 304 households have computers, 933 do not, and the computer owner ship rate of $24.6 \%$. In addition, all the computer owners initiatively connected to internet. Form the age perspective, the family with younger generation (80s) accounted for over $90 \%$ of the computer owners. From the aspect of the internet purpose, the production, education, obtaining information, recreation and entertainment accounted for $13.4 \%, 28.1 \%, 37.2 \%$ and $21.3 \%$, respectively. Therefore, as the education level improvement of the villagers, their capability of information acquiring is also elevated. Our survey also showed reasons impacting the network utilization: do not know how to use internet $(42.3 \%)$, do not need it $(27.1 \%)$ and have no money for it $(18.2 \%)$. The main reason would be that the cultural level is low for most villagers, and they are mainly involved in farming, resulting in a less prosperous life. However, they are all familiar with network, but have no convenient access to network. The major ways of obtaining information for farmers are TV, mobile phone and broadcast, accounting for $47.9 \%, 19.9 \%$ and $17.8 \%$, respectively, followed by newspapers and periodicals $6.9 \%$, home phone $5.5 \%$, internet $4.2 \%$, information station $2.7 \%$ and information machine $1.2 \%$. The main measure of information distribution is text, accounting for $19.9 \%$, then rural information station $11 \%$, internet $4.2 \%$, other ways $7.1 \%$ and the information machine $1.2 \%$.

The main reason would be that the cultural level is low for most villagers, and they are mainly involved in farming, resulting in a less prosperous life. However, they are all familiar with network, but have no convenient access to network. In addition, information awareness of rural residents in mountainous areas is not strong. Although the prevalence level of TV, mobile and computer is high in mountainous area, the usage and understanding of information are deficient. Moreover, because of the young migrant workers, elder people and women are mainly involved in farming, which inhibits the development of rural information.

\section{Related Suggestions}

The investigation revealed the low prosperous level in the peasant households in the economically weak rural area of Beijing, low cultural level relatively low, low village management level and simple management methods, so desired measures and methods cannot be effectively implemented at the village level. Therefore, the following problems are needed to be resolved to promote the construction and development of economically weak rural areas of Beijing via information means:

\subsection{Strengthen the Construction of Information Infrastructure in the Economically Weak Rural Areas of Beijing}

To strengthen the construction of the information infrastructure in rural regions, the optical fiber should be available in the village to establish the effective network environment. The local network should be constructed at village level by the way of enterprise service and government purchase to provide the free and effective access to the Internet for poor villagers.

\subsection{Reinforce the Education and Training of The Cultural and Scientific Knowledge}

The function of various information engineering should be effectively elaborated by the education and training of the cultural and scientific knowledge. The overall personal quality of the villagers and the ability of the farmers to obtain and participate in market competition will be enhanced through the establishment and improvement of the pyramid training mechanism of the information officers, that is, county to township, township to village, and village to household. 


\subsection{Establish a Well-developed Information Service Platform}

Based on the actual needs of the villagers, the market, technology, knowledge, life, work and other needs, establish highly efficient information service platform to achieve the collection, collation, publishing and trading of information resources by the connection to the logistics and financial system, so that the local villagers can easily get the production and living information they need.

\subsection{Strengthen the Training of the Ability to Use Information Technology for Village Leaders to Improve their Awareness of Information Service}

The understanding of information technology by village leaders directly affects the level of information construction in the village, so the government should strengthen the training of the ability to use information technology for village leaders to improve their awareness of information service.

\section{Conclusions}

Due to the backward information basis and low cultural level of the villages in the economically weak rural areas of Beijing, the information capability of the villagers should be improved gradually. As a science and technology service, it is the first to offer the construction service for the basic environment as much as possible. The information distribution can be used to influence, motivate and increase the information awareness and application capability, which services for the production and life and promotes the integrated development of all aspects of the industry.

\section{References}

1. C.L. Wang, J.R. Gai, C.P. Yang, Journal of Anhui Agri.Sci. 35, 4703 (2007)

2. Z.Z. Shu, H. Zhou, Y.Q. Wu, Anhui Agri. Sci. Bull. $19,5(2013)$

3. Z.W. Fan, Journal of Intelligent 31, 151 (2012)

4. S.J. Wang, G.Z. Sun, Chin. Agric. Sci. Bull. 26, 393 (2010)

5. X.C. Zhang, X.Y. Qin, X.X. Zhang, Journal of Beijing Agricultural Vocation College 22, 42 (2008)

6. W.M. Liu, M.F. Rahman, S. Thirumuruganathan, N. Zhang, and G. Das. Proceedings of the VLDB Endowment. 8, 12 (2015) 